\title{
Bioavailability of Dietary Polyphenols and the Cardiovascular Diseases
}

\author{
K. S. Shivashankara ${ }^{1}$ and S. N. Acharya ${ }^{2, *}$ \\ ${ }^{1}$ Indian Institute of Horticultural Research, Bangalore, India \\ ${ }^{2}$ Agriculture and Agri-Food Canada, Lethbridge Research Centre, Lethbridge, Alberta AB, T1J 4B1, Canada
}

\begin{abstract}
Epidemiological studies indicate that the higher intake of fruits and vegetables may reduce the risks of many degenrative diseases like cancer, cardiovascular disease, cataract etc. This is attributed mainly to the intake of dietary polyphenols as seen in Mediterranean diets. However, the bioavailability of polyphenols is reported to be low due to poor absorption in the gut, intestine and colon and depends on the type of compounds, chemical structure, food matrix, extent of conjugation and individual colon microflora. In general, flavonoids, aglycones and pure compounds are absorbed more when compared to the glycosides. Diversity in intestinal mocroflora also contributes to a great extent for the variation in absorption of polyphenols as seen in a few studies for the absorption of isoflavones. Among the polyphenols, isoflavones are known to be more bioavailable followed by phenolic acids, flavanols, flavanones, flavonols and lowest bioavailability was seen for anthocyanins and proanthocyanidins.
\end{abstract}

\begin{abstract}
Many human and animal studies have shown that dietary polyphenols reduce the cardiovascular diseases by inhibiting LDL oxidation, promoting vasodilation and by antiplatelet properties. However, the relationship between the level of polyphenols in plasma and their in vivo cardioprotective effects are poor. It is clear that more studies with improved methods are needed to understand the involvement of polyphenols in reducing the risks of degenerative diseases. In order to translate the in vitro results to in vivo, bioavailability of dietary polyphenols have to be increased significantly. One way to achieve this would be to study food preparation methods that can increase the bioavailability of these compounds through the use of different additives, cooking methods, enzymes and microorganisms. Microorganisms appear to play an important role in increasing the bioavailability of polyphenols by removing the conjugation and by breaking polyphenols into simpler absorbable phenols. We feel more bacteria and fungi should be used in food preparations such as yeasts for bread and wine making; lactic acid bacteria for fermenting idlies, dosas, curds; and Bacillus strains for soy fermentation products to increase bioavalability of polyphenols. Enzyme treated or microbial digested food may become the future of food industry. This article was written with a view to supplement Dr. R. B. Singh's life long ambition to prevent cardiovascular diseases through the use of diet and discuss the above points in greater detail.
\end{abstract}

Keywords: Dietary polyphenols, bioavailability, cardiovascular diseases, food preparation methods, processing.

\section{INTRODUCTION}

Atherosclerosis is the major cause of mortality in the western world, and involves interactions among cells of the arterial wall, blood cells, and plasma lipoproteins [1]. Epidemiological studies have shown the importance of fruit and vegetable enriched diets on the reduced risks of degenerative diseases and the effects have been attributed to presence of antioxidants in the diets [2, 3]. Inverse relationships between plant-derived foods and the risk of coronary heart disease have been reported by many workers [4-8].

Dr. Singh and his co-workers have studied the importance of consumption of fruits and vegetables, whole grains and almonds and walnuts (Indo-mediterrenean diets) [9-12], physical activity [13-15], w-3-fatty acid/w-6 fatty acid ratio [16], antioxidant vitamins [13, 17, 18], magnesium [19] for control of cardiovascular diseases (CVD). Role of

*Address correspondence to this author at the Agriculture and Agri-Food Canada, Lethbridge Research Centre, Lethbridge, Alberta AB, T1J 4B1, Canada; Tel: 1-403-317-2277; Fax: 1-403-382-3156;

Emails: acharya@agr.gc.ca, acharyasn@gmail.com nutraceuticals and the expression of genes involved in stress responses [20] in regulating the coronary artery disease have also been studied in detail by this group. Composition of a diet for reducing the risk of CVD in South Asian population has also been recommended [21]. Along with diets rich in nutraceuticals and high in w-3/w-6 fatty acids, the bioavailability of polyphenols are also important for better health benefits from fruits and vegetables.

Dietary antioxidant capacity is related mainly to the total polyphenol content of fruits and vegetables [22-26]. Polyphenols clearly improve the status of different oxidative stress biomarkers [27]. Much uncertainty, however, persists regarding both the relevance of these biomarkers as predictors of disease risk and the appropriateness of the different methods used [28]. It is well established that some polyphenols, administered as supplements with food, do improve health status, and this is indicated by several biomarkers of cardiovascular risk [29-31].

It is also now well established that polyphenols undergo substantial metabolism after ingestion and the plasma concentrations usually ranges from 0 to $4 \mu \mathrm{mol} / \mathrm{L}[32,33]$ in 
spite of their high concentration in the diet. Therefore, it is essential that we understand the mechanisms involved in the bioavailability of different polyphenols and their relevance for human health. This review will analyse the relationship between plasma concentrations of polyphenols and various factors affecting the atherosclerosis using human or animal intervention studies only rather than in vitro experiments.

\section{BIOAVAILABILITY OF POLYPHENOLS}

Physiologically active plasma concentration of phenolic compounds is dependent on the bioavailability of polyphenols in humans. Clifford [34] reported that daily intake of total polyphenols and tannins may range from less than 100 $\mathrm{mg}$ to in excess of $2 \mathrm{~g}$, with major contribution from coffee and tea. However, only $5 \%$ of the dietary polyphenol is absorbed in the duodenum. Over $95 \%$ of the intake passes to the colon and is fermented by the gut microflora. A fraction of the microbial metabolites is absorbed and appears in the plasma as mammalian conjugates. Many workers have explained the fate of polyphenols in human digestive system [35-38], a synthesis of this information is presented in pictorial form (Fig. 1) for easy understanding of the process.

\section{a) Flavonoids}

Flavonoid glycosides are absorbed to a limited extent [38] and are cleaved by gut bacterial or human intestinal $\beta$ glycosidases [39]. Flavonoid aglycons are conjugated in mucosa and liver by enzymes (UDP-glucuronosyltransferase, sulfotransferase, and catechol-O-methyltransferase) [40]. Bacteria in the lower intestine hydrolyze and metabolise the flavonoid conjugates after biliary excretion, which results in reabsorption of the flavonoid aglycons [40-42].

\section{Quercetin}

Quercetin is observed in plasma after the consumption of onions, tea, and apple juice [43-46]. Quercetin and its metabolites retain their antioxidant activity [36] in plasma.
Most abundant metabolites of quercetin in rats were the glucuronic and sulfate conjugates of isorhamnetin [36]. Benzoic acid derivatives have also been reported as the major metabolites of quercetin [47] probably due to microbial degradation [48].

\section{Catechins}

Epigallocatechin gallate and epicatechin gallate are detected in plasma and urine after tea consumption [49] and omethylcatechin after red wine consumption [50]. Gallic acid derivatives and 1,3,5-trimethoxybenzene were reported to be the major metabolites of epicatechin and epicatechin gallate in healthy humans [47]. Intake of $20 \mathrm{~g}$ cocoa significantly increased the metabolites (microbial) and conjugates of (-)-epicatechin, in $24 \mathrm{hr}$ urine and plasma samples of humans [48].

Manach et al., [32] in an exhaustive review of 97 bioavailability studies on humans concluded that the plasma concentrations of total metabolites ranged from 0 to 4 $\mu \mathrm{mol} / \mathrm{L}$ with an intake of $50 \mathrm{mg}$ aglycone equivalents, and the relative urinary excretion ranged from $0.3 \%$ to $43 \%$ of the ingested dose, depending on the polyphenol. Bioavailability of polyphenols have been ranked by some authors, a summary of the ranking is presented in Fig. (2).

\section{b) Phenolic Acids}

Variation in the absorption rates of phenolic acids in the gastric region was observed in rats. The absorption rate was in the order of p-coumaric acid > ferulic acid > caffeic acid > gallic acid > chlorogenic acid [53].

\section{Ferulic Acid}

This compound increased rapidly in plasma after the ingestion of tomatoes and beans [54] or beer [55] and reached peak urinary excretion at 7 or $8 \mathrm{~h}$ for tomatoes or beer, respectively and was observed in plasma [56-59]. Free acid are 10 to 17 times more bioavailable than esterified phenolic

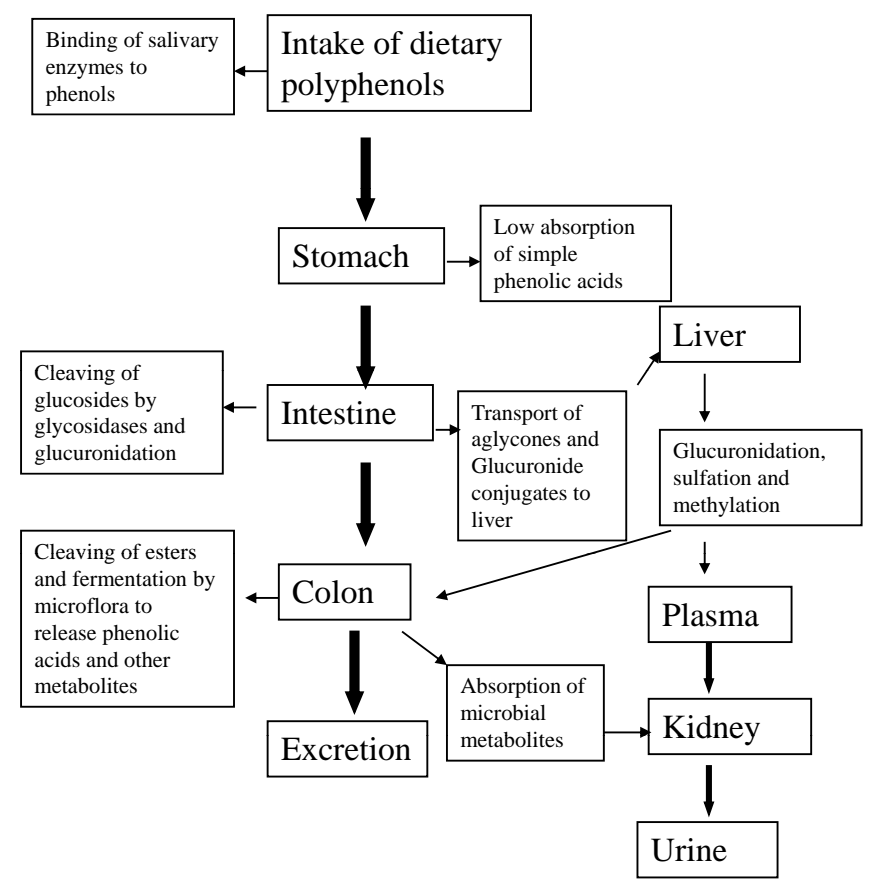

Fig. (1). Metabolism of polyphenols in humans. 


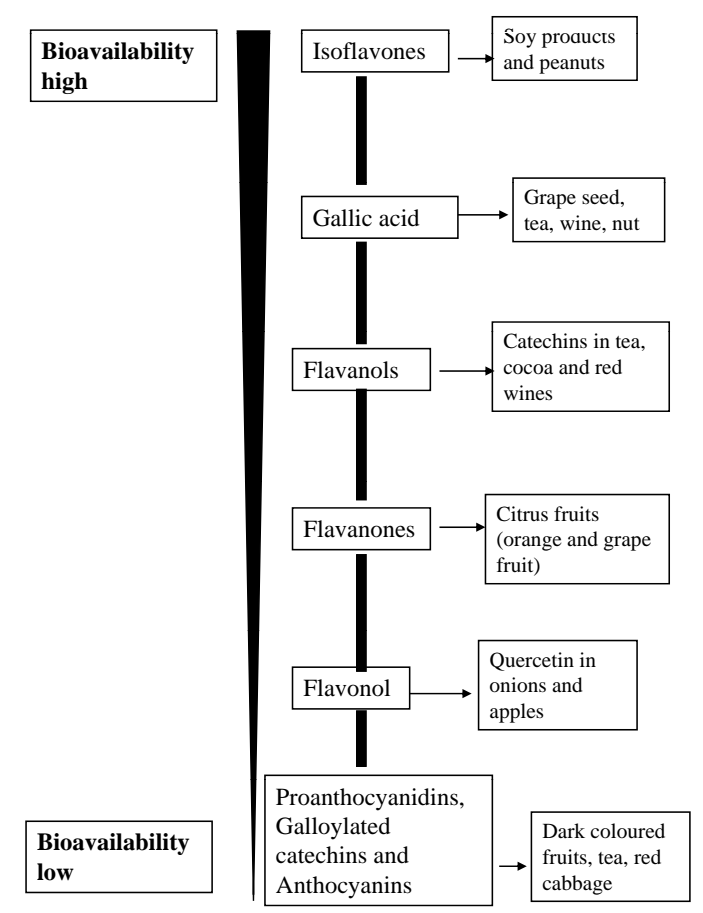

Fig. (2). Bioavailability ranking of polyphenols [Derived from; 32, 51, 52].

acids in humans [60-62]. Phenolic acids could be absorbed in stomach [53] and also intestine and the esterified acids will be metabolised by the colonic microflora.

\section{Chlorogenic Acid}

Plasma concentration and the rate of absorption of chlorogenic acid (ester of caffeic and quinic acid) were 100 and 2.4 times less respectively than that of caffeic acid [63, 64]. Urinary excretion of chlorogenic acid was only $0.3 \%$ [65]. Bioavailability was not affected by the additions such as milk or sugar in rats [66] and was found in plasma of humans after the consumption of coffee, prune or pure chlorogenic acid [67-69].

\section{Gallic Acid}

Plasma concentration of gallic acid reached $4.7 \mu \mathrm{M}$ after $2 \mathrm{~h}$ of Assam tea (200ml) (50 mg of GA) consumption and the urinary excretion was almost $40 \%$ [70] and this was similar to the absorption by the ingestion of pure gallic acid [71].

\section{Caffeic Acid}

Olthof et al. [65] showed in a human study that after ingestion of $2.8 \mathrm{mM}$ of caffeic acid $(505 \mathrm{mg}), 11 \%$ of the ingested dose was excreted in the urine. When volunteers consumed red wine, caffeic acid was detected in plasma [70, 72]. Wide variation among individuals for plasma caffeic acid $(58-176 \mathrm{ng} / \mathrm{ml})$ levels was reported when $200 \mathrm{ml}$ of coffee was given [73].

\section{Ellagic Acid}

Ellagic acid was found in plasma as ellagic acid and in urine as microbial metabolites in studies using pomegranates, strawberries, raspberries, walnuts or oak-aged wine [74-76].

The above discussion indicates that the phenolic acids are mainly absorbed in the intestine. Identification of microbial metabolites of phenolic acids in urine also indicate the role of colon microflora in the absorption of phenolic acids. Absorption of esterified form of phenolic acids like chlorogenic acid is significantly lower than the free phenolic acids since they have to be metabolised by the gut microflora before absorption.

\section{c) Proanthocyanidins and Anthocyanins}

Proanthocyanidins from chocolates are absorbed after they are metabolised by the gut microflora to many aromatic phenolic acids [77]. These phenolic acids have been found to have antioxidant and antilipid peroxidation activities [78]. Anthocyanin recovery in urine within $12 \mathrm{~h}$ of wine consumption in humans was to the extent of $1.5-5.1 \%$ only [79]. They are absorbed and transported in human serum and urine primarily as glucuronide and sulfate conjugates [80]. Main metabolites of anthocyanins were glucouronides and sulfates. When pigs were fed marionberry, pelargonidin was relatively more absorbed than cyanidin glucosides [81]. Delphinidn absorption was much less and di and tri saccharides of anthocyanins were found intact in urine. Only 1.5 to $1.8 \%$ of pelargonidin metabolites were found in urine after the intake of strawberry puree [82]. Variations in the absorption of different types of anthocyanins indicate that the absorption depends on the chemical structure and the type conjugation of the anthocyanins.

In addition to the plasma concentration or urinary excretion levels, concentration in target tissues is very important for them to be medically beneficial.

\section{d) Uptake of Polyphenols in Tissues}

In a study on rats using ferulic acid, hesperetin and genestein Silberberg et al. [83] reported that the extent of biliary and intestinal secretion into lumen as conjugates may indi- 
cate the lesser availability for tissues. According to them ferulic acid was more available than the other two.

Manach et al. [84] in their review have said that polyphenols are seen in various tissues like brain, endothelial cells, kidney, heart, spleen, pancreas, ovary, testis, prostrate, uterus, bone, skin etc, ranging from 3 to $3000 \mathrm{ng} / \mathrm{g}$ tissue. They have also cited a few human studies showing the accumulation of polyphenols in prostrate and breast tissues. Epicatechin and catechin were found in brains of rats when repeated feeding of grape seed extract was done instead of 1 acute feeding [85]. Second dosage of pure theaflavin digallte enhanced the tissue uptake in liver and uptake was enhanced when given with black tea extract [86]. Level of absorption of polyphenols and their concentration in target tissues are important for the health benfiting effects and this could be increased by repeated feeding instead of 1 acute intake.

\section{e) Variability among Individuals in Absorption Rates}

Interindividual variation in absorption of soy isoflavones has been observed [87]. Microbial degradation rate leads to interindividual differences in the absorption of flavonoids $[47,88]$ and formation of equol (metabolite with health benefits) from diadzein [89].

French were found to have more equol production followed by Italians and least was in Dutch indicating the variation was due to intestinal microbial activity [90]. Wide variations in plasma antioxidants can be expected between the individuals for the same intake of fruits and vegetables as seen in a human intervention study [91]. It would therefore be important to understand the influence of the diet on the type of gut microflora to maximize health benefits from polyphenols.

\section{PLASMA POLYPHENOL CONCENTRATION AS IT RELATES TO INHIBITION OF LDL OXIDATION}

The LDL oxidation plays a pivotal role in early atherogenesis $[92,93]$. The oxidative hypothesis of atherosclerosis has stimulated extensive investigation on the role of antioxidants as a possible preventive treatment for atherosclerosis.

Mediterranean diet known to have beneficial effects in reducing the cardiovascular diseases has about $68 \%$ of Total Dietary Antioxidant Capacity coming from beverages and $20 \%$ from fruits and vegetables, with a very low contribution from cereals. Total phenolics intake was estimated as 1171 $\mathrm{mg}$ gallic acid/person/day by the Folin-Ciocalteau method [94].

Fruits and Vegetable Polyphenols and Inhibition of LDL Oxidation

Quercetin metabolite accumulation after onion consumption was not enough to reduce the LDL oxidation in rats [95]. Ingestion of quercetin, kaempferol, myricetin and apigenin through fruits, vegetables and beverages by human subjects did increase plasma flavonoid content significantly but failed to show any direct effect on LDL protection [46]. Dietary supplementation of lycopene significantly increased serum lycopene levels by at least twofold and LDL oxidation was significantly decreased [96, 97].
Short-term supplementation of freeze-dried strawberries reduced the cholesterol levels and decreased lipid peroxidation in women [98]. Consumption of kiwifruit (2 fruits/day) for 8 weeks significantly reduced LDL oxidation [99]. The inhibition of LDL oxidation was shown in healthy as well as carotid artery stenosis (CAS) patients as well as in aged mice using pomegranate juice [100-102]. The protection of LDL was due to enhanced activity of serum paraoxanase-1 (PON-1) [101], reduced NADH-oxidase and increased activity of glutathione reductase by flavonoids [103, 104]. Consumption of cranberry vinegar $(200 \mathrm{ml}$ twice every day for 10 weeks) or cranberry juice $(7 \mathrm{ml} / \mathrm{kg} / \mathrm{day})$ or Concord grape juice $(10 \mathrm{ml} /$ day) reduced LDL oxidation and thiobarbituric acid reactive substances [105-107]. Concord grape juice effect was similar to alpha-Tocopherol (400 IU per day). Almond skin flavonoids (catechin, epicatechin, quercetin, kaempferol, and isorhamnetin) intake reduced plasma LDL oxidation by $18 \%$ and was synergistically increased to $52 \%$ when vitamin E was added [108]. Ingestion of soy isoflavonoids genistein $(12 \mathrm{mg})$ and daidzein $(7 \mathrm{mg})$ daily for 2 weeks by human subjects reduced the oxidation of LDLs [109].

\section{Cocoa Flavonoids}

Cocoa products reduced the LDL oxidation in humans [110]. Consumption of cocoa enriched chocolates or powders significantly reduced the LDL oxidation [111-113]. However in another human intervention study highflavonoid chocolate consumption did not show significant increase in inhibition of LDL oxidation and total antioxidant capacity [114]. Time of plasma sampling and dosage levels and also interindividual differences in absorption may be responsible for variation in results.

\section{Tea and Coffee Polyphenols and Inhibition of LDL Oxi- dation}

Green tea flavonoids inhibit the LDL oxidation through the protection of LDL-tocopherol and plasma ascorbic acid in ascorbic acid deficient mice [115] and in apoprotein (apo) E-deficient mice [116]. Enriched onion and black tea diet (high flavonoids) failed to reduce the lipid peroxidation marker in humans [117]. Daily consumption of green tea also decreased serum Malondialdehyde-LDL concentrations [118]. The resistance of LDL to oxidative modification increased significantly after coffee drinking (200ml/day) [119]. Drinking 8 cups of coffee per day significantly increased serum concentrations of total cholesterol, HDL cholesterol, and apolipoprotein A-I and decreased the ratios of LDL to HDL cholesterol [120].

\section{Grape Wine Polyphenols and Inhibition of LDL Oxidation}

Red wine has been found to be more potent than white wine or pure ethanol in this regard [121]. Grape-derived flavonoids and resveratrol limit ex vivo LDL oxidation [122, 123] and reduced atherosclerosis in rats [124]. Reduced atherosclerosis without a reduction in LDL oxidation within the arterial wall was observed following treatment with dealcoholized red wine in mice [125]. One drink of red wine, beer or stout was found to be beneficial but 3 drinks was 
pro-oxidant [126] and the pro-oxidant effect was due to ethanol metabolism.

Benito et al., [127] concluded that the intake of flavonoids will be beneficial only if there is an oxidative stress. Intake of too much polyphenol without the proportional increase in other vitamins may not be good since phenols at certain concentrations can act as prooxidants and initiate the LDL oxidation as reported for oleuropein and hydroxytyrosol [128]. Phenols may also produce phenoxy radicals and need ascorbic acid to scavenge them. Therefore, polyphenol supplements may not be beneficial as that of dietary polyphenols.

\section{Metabolites of Flavonoids and Inhibition of LDL Oxidation}

Conjugates of quercetin like quercetin glucuronides and sulfates have been found to be equally or more active than the glucoside or aglycone in inhibiting the LDL oxidation. The products of small intestine metabolism (quercetin-7glucuronide, quercetin-3-glucuronide) are more efficient antioxidants than subsequent liver metabolites such as isorhamnetin-3-glucuronide, quercetin-3'-sulfate. Albuminbound conjugates retained their property of protecting LDL from oxidation [129].

Although there are a few studies showing no effect of some flavonoids on inhibition of LDL oxidation, majority of the studies indicated a positive effect of consumption of fresh fruits and vegetables, as well as beverages such as coffee, tea and juice. Effect of polyphenols on LDL oxidation is summarised in Fig. (3).

\section{POLYPHENOLS AND VASODILATION}

Endothelial dysfunction is one of the earliest events in atherogenesis. A consequence of endothelial damage is low availability of nitric oxide (NO), the most potent endogenous vasodilator. Polyphenols and their metabolites have positive effects on the vasodilation of arteries.

\section{a) Fruit and Vegetables and Vasodilation}

Maize, cranberry and aubergine were found to have higher vasorealxation effect in vitro among many fruits, vegetables, nuts, tea and spices [130]. Intake of fruits and vegetables enriched diets and whole grains reduced the markers for endothelial dysfunction but high fat diet increased the marker levels $[131,132]$. Consumption of red wine or fruit and vegetables reversed the high fat induced decline in markers [133]. Consumption of orange and black- currant juice was better than vitamin E supplementation in human peripheral arterial patients [134]. Dose dependent response of endothelium mediated fore arm blood flow was observed for fruits and vegetables [91]. Flavonoids enhance vasodilation by increasing the NO synthase activity and expression, by scavenging the peroxynitrite-derived radicals, thereby protecting the cofactor tetrahydrobiopterin that is crucial for NO synthase activity and by reducing the activity of stress induced redox genes [135, 136]. Endothelium dependent vasodilation and reduction of NAD $(\mathrm{P}) \mathrm{H}$ dependent superoxide anions was seen for citrus extract and ferulic acid in rats [137, 138]. Endothelium independent vasodilation was reported for aqueous extract of Berberis vulgaris fruits [139]. However, intake of fruit and vegetable did not show any effect on endothelium independent vasodilation in a study on humans [140].

\section{b) Grape Products and Vasodilation}

Enhanced vasodilation through Nitric oxide production and NO synthase activity by red wine, grape juice, grape seed extracts and grape specific polyphenols [141-144] may be due to phosphorylation [145]. Polyphenols may increase NO synthesis through increased flux of $\mathrm{Ca}^{+2}$ in short term and expression of NO synthase in long term [146]. Red wine polyphenol extract was found to reduce the plasma homocysteine levels and endothelial dysfunction markers in rats [147]. Among the wine polyphenols kaempferol was found to be more effective in endothelium induced vasorelaxation in rats when compared to myricetin and rutin [148]. However, alcohol could cause a reduction in vasodilation when taken in high dosages and the polyphenols present in wine were unable to reverse it in humans [149].

Consumption of grape polyphenols equivalent to 1.25 cups of fresh grapes caused significant improvement in brachial artery flow mediated dilation in a dose dependent manner [150]. A protective effect of resveratrol on portal vein thrombosis was observed in rats [151]. In a recent review Schini-Kerth et al. [152] concludes that polyphenols induced endothelium-dependent relaxation also involves endothelium-derived hyperpolarizing factor, besides NO, in several types of arteries.

\section{c) Cocoa Products and Vasodilation}

In a human intervention study high-flavonoid chocolate consumption improved endothelium-dependent flowmediated dilation (FMD) (40\%) independent of plasma antioxidant activity [114] and through increased NO production [153]. Many studies have reported significant increase in

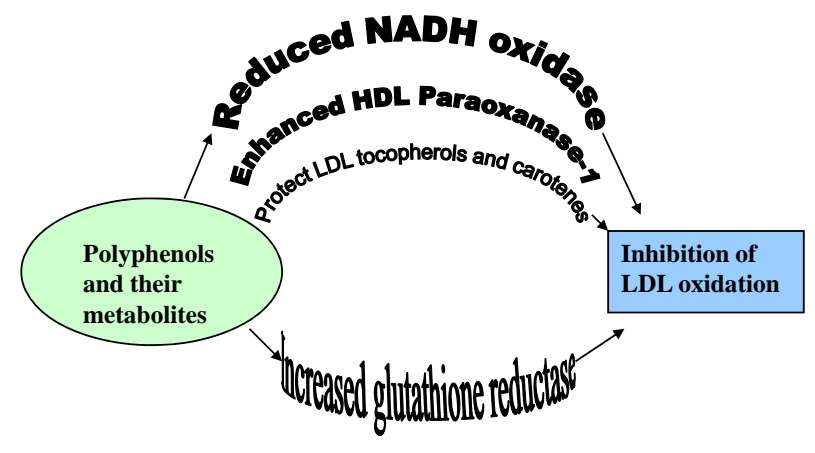

Fig. (3). Mechanism of LDL oxidation inhibition by polyphenols. 
flow mediated vasodilation after consumption of cocoa products [154-157]. Corti et al. [158] in their review summarise the major effects of cocoa flavonoids as increasing the bioavailability of endothelial NO, improvement in endothelial function, the reduction in platelet function.

\section{d) Tea and Coffee Polyphenols and Vasodialtion}

Consumption of black and green teas improved endothelium-dependent arterial vasodilation [159-162] mainly by increasing the NO synthase activity [163]. Attenuation of atherosclerotic lesion in apolipoprotein $\mathrm{E}(\mathrm{ApoE})^{-/-}$geneknockout mouse was by quercetin and theaflavin (tea polyphenol) indicate the beneficial effect of tea flavonoids [164].

Caffeinated coffee (100 mg of caffeine) was found to reduce the vasodilation in humans indicating the ill effects of caffeine on cardiovascular diseases [165]. On the contrary, caffeine at a dose of $300 \mathrm{mg}$ showed a positive effect on fore arm blood flow in young men [166] indicating the nitric oxide mediated vasorelaxation effect of caffeine. However, Riksen et al. [167] in a review on coffee and cardiovascular diseases concluded that the detrimental effect of coffee consumption in triggering the coronary events is only in selected patients and not in general population. A dose dependent positive effect of decaffeinated coffee on endothelium mediated vasorelaxation was seen in humans [168]. This indicates the beneficial effect of coffee without caffeine and the results on the effects of caffeine are not conclusive.

\section{e) Metabolites of Polyphenols and Vasodilation}

Isorhamnetin and a sulphate metabolite of quercetin were found to be more effective than quercetin [169] on endothelium independent vasorelaxation but quercetin glucouronide metabolite did not show any effect [170].

Dietary polyphenols from fruits, vegetables, tea, wine, juice and cocoa products were found to have significant vasodilation effects both in vivo and in vitro. Vasodilation effect was mainly brought about by the increased activity of endothelial nitric oxide synthase as well as by endothelial independent mechanisms. Dose dependent effects have been observed for some of the polyphenols indicating the importance of maintaining the plasma levels of polyphenols to get the significant health benefits.

\section{POLYPHENOLS AND PLATELET AGGREGATION}

Platelet aggregation is a crucial mechanism in the pathogenesis and clinical expression of coronary acute syndrome. Polyphenol supplementation, either as purified compounds or food extracts, showed some inhibitory effects, both in humans and in animal models. The observed inhibitory effect of polyphenols on platelet aggregation might explain and suggest a role for polyphenols in helping to prevent cardiovascular diseases [119].

\section{Grape Juice and Wine}

Grape juice consumption and resveratrol decreased platelet aggregation and superoxide production in healthy volunteers [141, 171]. Grape seed and skin in combination increased the antiplatelet effect [172] mainly due to the synergistic effect of polyphenols [173]. Antiplatelet effect of grape polyphenols was due to $\mathrm{Ca}^{+2}$ mobilisation mediated activation of the platelet endothelial cell adhesion molecule1 [174]. In an experiment on mice with pure compounds of resveratrol, quercetin and gallic acid it was observed that resveratrol and quercetin can inhibit arachidonic acidinduced platelet aggregation but not gallic acid mainly due to the interaction of gallic acid at the level platelet COX-1 enzyme [175]. Dealcoholised red wine completely inhibited the ADP induced platelet aggregation, procyanidins, catechins and monomeric anthocyanidins fraction of red wine also reduced the platelet aggregation whereas, flavonols, resveratrol and polymeric anthocyanidin fraction did not show any effect on platelet aggregation [176].

\section{Fruits}

Berry consumption at a dose of $160 \mathrm{~g} / \mathrm{d}$ (total polyphenols $837 \mathrm{mg} / \mathrm{d}$ ) did not show any effect on plasma biomarkers of platelet aggregation however, did show an increased inhibition of platelet aggregation ex vivo [177]. Consumption of 2 or 3 kiwi fruits for 28 days reduced platelet aggregation [178]. Antiplatelet effect has been reported for tomato [179] and resvereatrol [180], grape seed extract, chokeberry extracts [181] and mulberry [182]. Pomegranate juice and pomegranate fruit extracts were effective in reducing platelet aggregation, calcium mobilization, thromboxane $A_{2}$ production and hydrogen peroxide formation, induced by collagen and arachidonic acid [183]. Other beverages, such as orange juice and grapefruit juice did not show antiplatelet effect [184].

\section{Cocoa}

Dietary flavanols from cocoa inhibit the platelet aggregation $[155,185-189]$ suppressed platelet activation and platelet micro particle formation in humans [190]. Short-term cocoa polyphenol supplementation did not decrease platelet activity in response to exercise in humans [191]. Cocoa consumption had an aspirin-like effect on primary haemostasis and suppressed unstimulated and stimulated platelet activation in whole blood and was found to be better than dealcoholised red wine or pure procyanidins in healthy subjects [187].

Flavonoids like quercetin, apigenin and genistein have been shown to reduce the thrombin responses by interfering in the intracellular signalling and through inhibition of kinases [192]. Polyphenol rich meal every lunch time for 5 days did not show any significant change in ex vivo platelet aggregation even though plasma level of flavonoids increased significantly [172] may be due to less than the effective concentration of flavonoids [193, 194].

\section{Olive Oil}

Virgin olive oil polyphenol hydroxytyrosol acetate inhibits in vitro platelet aggregation in human whole blood when compared to acetyl salicylic acid. This effect involved a decrease in platelet thromboxane synthesis and an increase in leukocyte nitric oxide production $[195,196]$.

\section{Tea}

Tea consumption reduces platelet activation and plasma C-reactive protein in healthy men [197]. Tea polyphenols alleviated the thrombosis in a dose dependent manner in rab- 
bits [198]. Hernandez Figueroa et al. [199] suggest that a daily intake of 7 cups of green tea is a good measure for coronary heart disease prevention. However, tea consumption could not show any effect after high fat diet intake in humans [200].

\section{Synergistic Effect of Polyphenols}

Anthocyanins, metabolites of polyphenols of colonic origin and their mixture showed significant dose dependent activity against platelet aggregation and activation [201] and the mixtures were more active than the individual compounds indicating the synergistic effect. Synergistic effect was also reported for quercetin and catechin in reducing platelet recruitment further proves that the polyphenols are more effective in combination [202].

Results indicate that the polyphenols have a significant antiplatelet effect when tried under in vitro conditions. Most of the studies have been done using polyphenol extracts against isolated platelets. However, the ex vivo studies using animals and humans have given mixed results. Therefore more animal and human experiments are required to conclusively prove the antiplatelet effects of polyphenols. Use of proper biomarkers for platelet aggregation status of the blood may improve the reliability of results instead of ex vivo experiments. Significant synergistic effects of polyphenols have been reported indicating the benefits of having diets with a mixture of polyphenols. Therefore, inclusion of a combination of fruits and vegetables in diet is more beneficial rather than having only a few items.

\section{METHODS OF FOOD PREPARATION AND THE BIOAVAILABILITY OF POLYPHENOLS AND OTHER NUTRIENTS}

Diets with high fats and meats increased the inflammation and endothelial dysfunction markers whereas, diets with fruits, nuts and vegetables and whole grains had significantly reduced the markers [131, 132] indicating importance of dietary components as well the food preparation methods of these diets. Food preparation methods may have an influence on the bioavailability of polyphenols and indirectly on human health.

\section{Polyphenol Content and Food Preparation}

Changes in polyphenol content of diets with various methods of cooking and food processing is given in Table $\mathbf{1}$.

Table 1. Change in Polyphenols Due to Various Cooking and Processing Methods

\begin{tabular}{|c|c|c|c|}
\hline Methods & Polyphenols & Food & Reference \\
\hline Cutting & Increase in cyanidin & Red lettuce & {$[203]$} \\
\hline \multirow[t]{2}{*}{ Shredding } & Decreased cyanidin & Red onions & {$[204]$} \\
\hline & Decreased cyanidin & Red oak, Lollo Rosso & [205] \\
\hline Juicing & $68 \%$ loss in anthocyanins & Berries & [206] \\
\hline Steaming and juicing & $85 \%$ loss in quercetin and $70 \%$ in myricetin & Billberries & {$[207]$} \\
\hline \multirow{4}{*}{$\begin{array}{l}\text { Cooking in water } \\
\text { (Boiling) }\end{array}$} & Loss in anthocyanins & Berries & {$[208]$} \\
\hline & $70-85 \%$ loss in quercetin and kaempferol & Broccoli & {$[209]$} \\
\hline & Increased polyphenols & Carrot, Onion and Potato & [210] \\
\hline & Decreased polyphenols & Broccoli and White cabbage & {$[210]$} \\
\hline \multirow[t]{4}{*}{ Steam cooking } & Increased polyphenol, carotenoids and tocopherols & Broccoli & {$[211]$} \\
\hline & No reduction in kaempferol & Red beans & {$[212]$} \\
\hline & Increase in polyphenols & Onions and Broccoli & {$[210]$} \\
\hline & Deceased polyphenols & White cabbage, potato and carrot & {$[210]$} \\
\hline Shallow frying & Antioxidant capacity increased but $20 \%$ loss in polyphenols & Vegetables & {$[213]$} \\
\hline Frying & No loss of anthocyanin & Sweet potato & {$[214]$} \\
\hline Microwave heating & Reduce loss of polyphenols & Olive oil & {$[215]$} \\
\hline \multirow[t]{3}{*}{ Mocrowave cooking } & Reduced lipid peroxidation & Vegetables & {$[216]$} \\
\hline & Increased polyphenols & Potatoes, onion and carrots & {$[210]$} \\
\hline & Decreased polyphenols & White cabbage & {$[210]$} \\
\hline Boiling and frying & Increased lipid peroxidation & Vegetables & {$[216]$} \\
\hline Blanching & Reduced polyphenols & Fenugreek leaves & {$[217]$} \\
\hline Soaking and dehulling & Reduced polyphenols & Foxtail millet & {$[218]$} \\
\hline Germination & Greater loss of polyphenols & & {$[219]$} \\
\hline Fermentation & Increased superoxide scavenging ability & Soy germ & {$[220]$} \\
\hline Osmotic dehydration & $25 \%$ loss of polyphenol & Apples & [221] \\
\hline
\end{tabular}




\section{Bioavailability of Polyphenols and Food Preparation}

\section{Processing}

Lycopene is more readily absorbed from processed tomato paste and puree at 308 fold higher rate than raw tomatoes as it is released from the cellular matrix during processing [222-224]. Higher uptake of lycopene from processed and cooked tomatoes is mainly due to the conversion of trans to cis-lycopene [222, 225, 226]. The cis-Lycopene increased by 5 fold due to heat processing of guava juice [227]. However, processing of blackcurrant had no significant effect on the oral bioavailability of anthocyanins [228].

\section{Food Additives and Bioavailability}

\section{Milk, Juice and Fat}

Addition of milk to various foods affects the polyphenol absorption, however the results are not uniform [229-234]. Addition of fat increased the absorption of flavonoids in cocoa and strawberries [235, 236]. However, addition of yogurt to orange juice or cream to strawberries did not influence the uptake of flavonoids [237]. Food matrix like wine or juice did not affect the absorption of quercetin or catechin [238]. Addition of $10 \% \mathrm{NaCl}$ and wheat dietary fibres to soybean resulted in loss of isoflavones and reduced absorption respectively [239, 240]. Isoflavone bioavailability did not vary significantly when soybean isoflavones were ingested by human subjects mixed with juice, cookies and bars [241]. Similar serum isoflavones and equol values were observed in this case. It is indeed worthwhile to study the effect of addition of salt, sugars, acids, oils and spices during food preparation on the bioavailability of polyphenols.

\section{Cooking and Bioavailability of Polyphenols}

Cooking increased the bioavailability of kaempferol from seed coats of beans [212]. Extrusion cooking of sorghum (flavonoids), cooking of tomatoes (naringenin and chlorogenic acid), carrots and broccoli (carotenes) increased the bioavailability [242-244].

\section{Fermentation, Enzyme Treatment and Bioavailability of Polyphenols}

Bacterial fermentation of soy products increased the bioavailability of isoflavones, saponins, phytosterols, tocopherols and superoxide scavenging ability when compared to seed based products $[217,245-249]$ mainly due to the formation of isoflavone aglycones.

From the available literature we can conclude that fermentation of foods can increase the bioavailability of isoflavones, addition of little fat, disruption of food matrix and cooking can increase the bioavailability of certain polyphenols, lycopenes and carotenoids. Food additives like salt can reduce the bioavailability of some polyphenols whereas fibres can delay but may improve the absorption.

\section{DIFFERENT METHODS TO INCREASE THE BIOAVAILABILITY AND EFFICIENCY OF PLANT BASED POLYPHENOLS}

Only a few methods were reported to increase the bioavailability of polyphenols as listed in Table 2.

More work needs to be done on increasing the bioavailability of polyphenols using different food preparation methods, instead of increasing the polyphenol content of fruits and vegetables. Many fruit and vegetables already have

Table 2. Bioavailability of Polyphenols from Foods Prepared Using Different Methods

\begin{tabular}{|c|c|c|c|}
\hline Methods & Food & Absorption & Reference \\
\hline $\begin{array}{l}\text { Fermentation with Bacillus subtilis strain } \\
\text { or Aspergillus fungi }\end{array}$ & Cooked soybeans and soy flour & Increased isoflavones & {$[250]$} \\
\hline $\begin{array}{l}\text { Enzyme digestion with beta-glycosidase } \\
\text { and fermentation }\end{array}$ & Soy milk & Increased isoflavones & [251] \\
\hline \multirow[t]{2}{*}{ Liquid versus solid form } & Soy milk versus textured vegetable protein & Increased absorption from soy milk & [252] \\
\hline & Soy milk, bar and powdered drink & Increased from soymilk & [253] \\
\hline \multicolumn{4}{|l|}{ Additives } \\
\hline Raspberry to bread or ice cream & Raspberry phenols & Decreased phenol & [254] \\
\hline Raspberry with mince & Raspberry anthocyanins & Increased anthocyanin & [254] \\
\hline Fat salad dressing or addition of fat & Vegetable salads & Increased carotenoid absorption & {$[255,256]$} \\
\hline $\begin{array}{l}\text { Ascorbic acid, Sucrose or soy milk or } \\
\text { bovine milk or fruit juice }\end{array}$ & With Tea & Increased recovery and absorption of catechins & [257-259] \\
\hline Piperine to curcumin & Curcumin & Increased absorption of curcumin & [260] \\
\hline Piperine & Epigallocatechin gallate from tea & 2 fold increase & [261] \\
\hline \multicolumn{4}{|l|}{ Frequency } \\
\hline More frequent versus single acute intake & Grape seed polyphenol extract & $\begin{array}{l}2-3 \text { fold increase in gallic acid, catechin and } \\
\text { epicatechin absorption }\end{array}$ & {$[85]$} \\
\hline
\end{tabular}


a high content of polyphenols. Polyphenol content is very high in cocoa, tea and coffee and also in red wines but the bioavailability is considered very poor in these plant based products. Therefore one of the challenging areas of work would be to increase the bioavailability of dietary polyphenols using food preparation methods. Available literature indicate that disruption of food matrix, addition of fat, cooking, treatment with enzymes, addition of ascorbic acid, milk and fermentation can increase the bioavailability of dietary polyphenols. We believe a good understanding of polyphenols and increasing their bioavailability will go a long way to prevent cardiovascular diseases, a major area of interest Dr. R. B. Singh has.

\section{REFERENCES}

[1] Glass CK, Witztum JL. Atherosclerosis: The road ahead. Cell 2001; 104: 503-16.

[2] Arts ICW, Hollman PCH. Polyphenols and disease risk in epidemiologic studies. Am J Clin Nutr 2005; 81: 317-25.

[3] Dohadwala MM, Vita JA. Grapes and cardiovascular disease (Grapes and health.). J Nutr 2009; 139: 1788-93.

[4] Hertog MG, Kromhout D, Aravanis C, et al. Flavonoid intake and long-term risk of coronary heart disease and cancer in the seven countries study. Arch Intern Med 1995; 155: 381-6.

[5] Hertog MG, Feskens EJ, Hollman PC, Katan MB, Kromhout D. Dietary antioxidant flavonoids and risk of coronary heart disease: the Zutphen Elderly Study. Lancet 1993; 342: 1007-11.

[6] Joshipura KJ, Hu FB, Manson JE, et al. The effect of fruit and vegetable intake on risk for coronary heart disease. Ann Intern Med 2001; 134: 1106-14.

[7] Keli SO, Hertog MG, Feskens EJ, Kromhout D. Dietary flavonoids, antioxidant vitamins, and incidence of stroke: the Zutphen study. Arch Intern Med 1996; 156: 637-42.

[8] Knekt P, Jarvinen R, Reunanen A, Maatela J. Flavonoid intake and coronary mortality in Finland: a cohort study. BMJ 1996; 312: 47881.

[9] Singh RB, Rastogi SS, Niaz MA, Ghosh S, Singh R. Effects of fatmodified and fruits vegetable enriched diets on blood lipids in the Indian diet heart study. Am J Cardiol 1992; 69: 869-74.

[10] Singh RB, Rastogi SS, Ghosh S, Singh R, Niaz MA. Effects of guava intake on serum total and high density lipoprotein cholesterol levels and on systemic blood pressure. Am J Cardiol 1992; 70: 1287-91.

[11] Singh RB, Mori H, Chen J, et al. Recommendations for the prevention of coronary artery disease in Asians: a scientific statement of the International College of Nutrition. J Cardiovas Risk 1996; 3: 489-94.

[12] Singh RB, Dubnov G, Niaz MA, et al. Effect of an IndoMediterranean diet on progression of coronary disease in high risk patients: a randomized single blind trial. Lancet 2002; 60: 1455-61.

[13] Singh RB, Rastogi SS, Sircar AR, Mani UV, Singh NK, Niaz MA. Effect of lifestyle changes on atherosclerotic risk factors in the Indian diet heart study. Am J Cardiol 1993; 71: 1283-8.

[14] Singh RB, Singh V, Kulshrestha SK, et al. Social class and all cause mortality in the urban population of north India. Acta Cardiol 2005; 60: 611-7.

[15] Singh RB, Pella D, Mechirova V, et al. Prevalence of obesity, physical inactivity and undernutrition, a triple burden of diseases during transition in a developing economy. The Five City Study Group. Acta Cardiol 2007; 62: 119-27.

[16] Singh RB, Niaz MA, Kartik C. Can omega -3 fatty acids provide myocardial protection by decreasing infarct size and inhibiting atherothrombosis? Eur Heart J 2001; 3: 62-9.

[17] Singh RB, Niaz MA, Bishnoi I, et al. Diet, antioxidant vitamins, oxidative stress and risk of coronary artery disease: the Peerzada Prospective Study. Acta Cardiol 1994; 49: 453-67.

[18] Singh RB, Niaz MA, Agarwal P, Beegum R, Rastogi SS. Effect of antioxitant rich foods on plasma ascorbic acid, cardiac enzyme and lipid peroxide levels in patients hospitalized with acute myocardial infarction. J Am Diet Assoc 1995; 95: 775-80.
[19] Singh RB. Effect of dietary magnesium supplementation in the prevention of coronary heart disease and sudden cardiac death. Magnesium Trace Elem 1990; 9: 143-51.

[20] Sanjay Mishra, Singh RB, Dwivedi SP, et al. Effects of nutraceuticals on genetic expressions. Open Nutra J 2009; 2: 70-80.

[21] Singh RB, Tomlinson B, Thomas GN, Sharma R. Coronary artery disease and coronary risk factors: the South Asian paradox. J Nutr Environ Med 2001; 11: 43-51.

[22] Beltran-Orozco MC, Oliva-Coba TG, Gallardo-Velazquez T, Osorio-Revilla G. Ascorbic acid, phenolic content, and antioxidant capacity of red, cherry, yellow and white types of pitaya cactus fruit (Stenocereus stellatus Riccobono). Agrociencia (Montecillo) 2009; 43: 153-62.

[23] Hanson PM, Yang RY, Wu J, et al. Variation for antioxidant activity and antioxidants in tomato. J Am Soc Hort Sci 2004; 129: 70411.

[24] Kubola J, Siriamornpun S. Phenolic contents and antioxidant activities of bitter gourd (Momordica charantia L.) leaf, stem and fruit fraction extracts in vitro. Food Chem 2008; 110(4): 881-90.

[25] Leccese A, Bartolini S, Viti R. Total antioxidant capacity and phenolics content in apricot fruits. Int J Fruit Sci 2007; 7: 3-16.

[26] Wang SY, Chen CT, Sciarappa W, Wang CY, Camp MJ. Fruit quality, antioxidant capacity, and flavonoid content of organically and conventionally grown blueberries. J Agri Food Chem 2008; 56: 5788-94.

[27] Williamson GS, Manach C. Bioavailability and bioefficacy of polyphenols in humans. II. Review of 93 intervention studies. Am J Clin Nutr 2005; 81(suppl): 243S-55S.

[28] Collins AR. Assays for oxidative stress and antioxidant status: applications to research into the biological effectiveness of polyphenols. Am J Clin Nutr 2005; 81: 261-7.

[29] Keen CL, Holt RR, Oteiza PI, Fraga CG, Schmitz HH. Cocoa antioxidants and cardiovascular health. Am J Clin Nutr 2005; 81(suppl): 298S-303S.

[30] Sies H, Schewe T, Heiss C, Kelm M. Cocoa polyphenols and inflammatory mediators. Am J Clin Nutr 2005; 81(suppl): 304S-12S.

[31] Vita JA. Polyphenols and cardiovascular disease: effects on endothelial and platelet function Am J Clin Nutr 2005; 81(suppl): 292S$7 \mathrm{~S}$.

[32] Manach C, Williamson G, Morand C, Scalbert A, Rémésy C. Bioavailability and bioefficacy of polyphenols in humans. I. Review of 97 bioavailability studies. Am J Clin Nutr 2005; 81(suppl): 230S-42S.

[33] Rio D, del Costa LG, Lean MEJ, Crozier A. Polyphenols and health: what compounds are involved? Nutr Metab Cardiovasc Dis 2010; 20: 1-6.

[34] Clifford MN. Diet-derived phenols in plasma and tissues and their implications for health. Planta Med 2004; 70: 1103-11.

[35] Bravo L. Polyphenols: Chemistry, dietary sources, metabolism, and nutritional significance. Nutr Rev 1998; 56: 317-33.

[36] Morand C, Crespy V, Manach C, Besson C, Demigne C, Remesy C. Plasma metabolites of quercetin and their antioxidant properties. Am J Physiol 1998; 275: 212-9.

[37] Piskula MK, Terao J. Accumulation of (-) epicatechin metabolites in rat plasma after oral administration and distribution of conjugation enzymes in rat tissues. J Nutr 1998; 128: 1172-8.

[38] Scalbert A, Williamson G. Dietary intake and bioavailability of polyphenols. J Nutr 2000; 130: 2073-8.

[39] Day AJ, Gee JM, DuPont S, Johnson IT, Williamson G. Absorption of quercetin-3-glucoside and quercetin-40 0 -glucoside in the rat small intestine: the role of lactase phlorizin hydrolase and the sodium-dependent transporter. Biochem Pharmacol 1999; 65: 1199-206.

[40] Crespy V, Morand C, Manach C, Besson C, Demigne C, Remesy C. Part of quercetin absorbed in the small intestine is conjugated and further secreted in the intestinal lumen. Am J Physiol 1999; 277: $120-6$.

[41] Liu Y, Hu M. Absorption and metabolism of flavonoids in the Caco-2 cell culture model and a perused rat intestinal model. Drug Metab Dispos 2002; 30: 370-7.

[42] Turner NJ, Thomson BM, Shaw IC. Bioactive isoflavones in functional foods: the importance of gut microflora on bioavailability. Nutr Rev 2003; 61: 204-13. 
[43] Hollman PC, Van Trijp JM, Mengelers MJ, De Vries JH, Katan MB. Bioavailability of the dietary antioxidant flavonol quercetin in man. Cancer Lett 1997; 114: 139-40.

[44] Manach C, Morand C, Crespy V, et al. Quercetin is recovered in human plasma as conjugated derivatives which retain antioxidant properties. FEBS Lett 1998; 426: 331-6.

[45] Lean ME, Noroozi M, Kelly I, et al. Dietary flavonols protect diabetic human lymphocytes against oxidative damage to DNA. Diabetes 1999; 48: 176-81.

[46] McAnlis GT, McEneny J, Pearce J, Young IS. Absorption and antioxidant effects of quercetin from onions, in man. Eur J Clin Nutr 1999; 53: 92-6.

[47] Loke W, Jenner AM, Proudfoot JM, et al. A Metabolite profiling approach to identify biomarkers of flavonoid intake in humans. J Nutr 2009; 139: 2309-14

[48] Urpi-Sarda M, Monagas M, Khan N, et al. Targeted metabolic profiling of phenolics in urine and plasma after regular consumption of cocoa by liquid chromatography-tandem mass spectrometry. (Special Issue: Advanced separation methods in food analysis.) $\mathbf{J}$ Chromatogr A 2009; 1216: 7258-67.

[49] Yang CS, Chen L, Lee MJ, Balentine D, Kuo MC, Schantz SP. Blood and urine levels of tea catechins after ingestion of different amounts of green tea by human volunteers. Cancer Epidemiol Biomarkers Prev 1998; 7: 351-5.

[50] Donovan JL, Bell JR, Fasim-Karakas S, et al. Catechin is present as metabolites in human plasma after consumption of red wine. $\mathbf{J}$ Nutr 1999;129: 1662-8.

[51] D'Archivio M, Filesi C, Benedetto RD, Gargiulo R, Giovannini C, Masella R. Polyphenols, dietary sources and bioavailability. Ann $1^{\text {st }}$ Super Sanità 2007; 43: 348-61

[52] Viskupičová J, Ondrejovič M, Šturdík E. Bioavailability and metabolism of flavonoids. J Food Nutr Res 2008; 47:151-62.

[53] Konishi Y, Zhao Z, Shimizu M. Phenolic acids are absorbed from the rat stomach with different absorption rates. J Agric Food Chem 2006; 54: 7539-43.

[54] Bourne LC, Rice-Evans C. Bioavailability of ferulic acid. Biochem Biophys Res Commun 1998; 253: 222-7.

[55] Bourne L, Paganga G, Baxter D, Hughes P, Rice-Evans C. Absorption of ferulic acid from low-alcohol beer. Free Radic Res 2000; 32: $273-80$.

[56] Zhao Z, Egashira Y, Sanada H. Ferulic acid is quickly absorbed from rat stomach as the free form and then conjugated mainly in liver. J Nutr 2004; 134: 3083-8.

[57] Rondini L, Peyrat-Maillard MN, Marsset-Baglieri A, Berset C. Sulfated ferulic acid is the main in vivo metabolite found after short-term ingestion of free ferulic acid in rats. J Agric Food Chem 2002; 50: 3037-41.

[58] Zhao Z, Egashira Y, Sanada H. Ferulic acid sugar esters are recovered in rat plasma and urine mainly as the sulfoglucuronide of ferulic acid. J Nutr 2003; 133: 1355-61.

[59] Rondini L, Peyrat-Maillard MN, Marsset-Baglieri A, et al. Bound ferulic acid from bran is more bioavailable than the free compound in rat. J Agric Food Chem 2004; 52: 4338-43.

[60] Adam A, Crespy V, Levrat-Verny MA, et al. The bioavailability of ferulic acid is governed primarily by the food matrix rather than its metabolism in intestine and liver in rats. J Nutr 2002; 132: 196268.

[61] Kern SM, Bennett RN, Mellon FA, Kroon PA, Garcia-Conesa MT. Absorption of hydroxycinnamates in humans after high-bran cereal consumption. J Agric Food Chem 2003; 51: 6050-5.

[62] Konishi Y, Hitomi Y, Yoshida M, Yoshioka E. Pharmacokinetic study of caffeic and rosmarinic acids in rats after oral administration. J Agric Food Chem 2005; 53: 4740-6.

[63] Azuma K, Ippoushi K, Nakayama M, Ito H, Higashio H, Terao J. Absorption of chlorogenic acid and caffeic acid in rats after oral administration. J Agric Food Chem 2000; 48: 5496-5500.

[64] Lafay S, Morand C, Manach C, Besson C, Scalbert A. Absorption and metabolism of caffeic acid and chlorogenic acid in the small intestine of rats. Br J Nutr 2006; 96: 1-8.

[65] Olthof MR, Hollman PCH, Katan MB. Chlorogenic acid and caffeic acid are absorbed in humans. J Nutr 2001; 131: 66-71.

[66] Dupas C, Marsset Baglieri A, Ordonaud C, Tome D, Maillard M. Chlorogenic acid is poorly absorbed, independently of the food ma- trix: a Caco-2 cells and rat chronic absorption study. Mol Nutr Food Res 2006; 50: 1053-60.

[67] Cremin P, Kasim-Karakas S, Waterhouse AL. LC/ES-MS detection of hydroxycinnamates in human plasma and urine. J Agric Food Chem 2001; 49: 1747-50.

[68] Ito H, Gonthier M, Manach C, et al. Polyphenol levels in human urine after intake of six different polyphenol-rich beverages. Br J Nutr 2005; 94: 500-9.

[69] Monteiro M, Farah A, Perrone D, Trugo LC, Donangelo C. Chlorogenic acid compounds from coffee are differentially absorbed and metabolized in humans. J Nutr 2007; 137: 2196-201.

[70] Cartron E, Fouret G, Carbonneau MA, et al. Red-wine beneficial long-term effect on lipids but not on antioxidant characteristics in plasma in a study comparing three types of wine-description of two O-methylated derivatives of gallic acid in humans. Free Radic Res 2003; 37: 1021-35.

[71] Shahrzad S, Aoyagi K, Winter A, Koyama A, Bitsch I. Pharmacokinetics of gallic acid and its relative bioavailability from tea in healthy humans. J Nutr 2001; 131: 1207-10.

[72] Abu-Amsha Caccetta RA, Croft KD, Beilin LJ, Puddey IB. Ingestion of red wine significantly increases plasma phenolic acid concentrations but does not acutely affect ex vivo lipoprotein oxidizability. Am J Clin Nutr 2000; 71: 67-74.

[73] Nardini M, Cirillo E, Natella F, Scaccini C. Absorption of phenolic acids in humans after coffee consumption. J Agric Food Chem 2002; 50: 5735-41.

[74] Cerda B, Periago P, Espin JC, Tomas-Barberan FA. Identification of urolithin a as a metabolite produced by human colon microflora from ellagic acid and related compounds. J Agric Food Chem 2005; 53: 5571-6.

[75] Cerda B, Tomas-Barberan FA, Espin JC. Metabolism of antioxidant and chemopreventive ellagitannins from strawberries, raspberries, walnuts, and oak-aged wine in humans: identification of biomarkers and individual variability. J Agric Food Chem 2005; 53: 227-35.

[76] Mertens-Talcott SU, Jilma-Stohlawetz P, Rios J, Hingorani L, Derendorf H. Absorption, Metabolism, and Antioxidant Effects of Pomegranate (Punica granatum L.) Polyphenols after ingestion of a standardized extract in healthy human volunteers. J Agric Food Chem 2006; 54: 8956-61.

[77] Rios LY, Gonthier MP, Remesy C, et al. Chocolate intake increases urinary excretion of polyphenol-derived phenolic acids in healthy human subjects. Am J Clin Nutr 2003; 77: 912-8.

[78] Wang JF, Schramm DD, Holt RR, et al. A dose-response effect from chocolate consumption on plasma epicatechin and oxidative damage. J Nutr 2000; 130: 2115S-9S.

[79] Lapidot T, Harel S, Granit R, Kanner J. Bioavailability of red wine anthocyanins as detected in human urine. J Agric Food Chem 1998; 46: 4297-302.

[80] Wu X, Cao G, Prior RL. Absorption and metabolism of anthocyanins in elderly women after consumption of elderberry or blueberry. J Nutr 2002; 132: 1865-71.

[81] Wu X, Pittman HE, Prior RL. Pelargonidin is absorbed and metabolized differently than cyanidin after marionberry consumption in pigs. J Nutr 2004; 134: 2603-10.

[82] Carkeet C, Clevidence BA Novotny JA. Anthocyanin Excretion by Humans Increases Linearly with Increasing Strawberry Dose. J Nutr 2008; 138: 897-902.

[83] Silberberg M, Morand C, Mathevon T, et al. The bioavailability of polyphenols is highly governed by the capacity of the intestine and of the liver to secrete conjugated metabolites. Eur J Nutr 2006; 45: 88-96.

[84] Manach C, Scalbert A, Morand C, Rémésy C, Jiménez L. Polyphenols: food sources and bioavailability. Am J Clin Nutr 2004; 79: 727-7.

[85] Ferruzzi MG, Lobo JK, Janle EM, et al. Bioavailability of gallic acid and catechins from grape seed polyphenol extract is improved by repeated dosing in rats: implications for treatment in Alzheimer's disease. J Alzheimers Dis 2009; 18: 113-24.

[86] Maity S, Ukil A, Vedasiromoni JR, Das PK. Biodistribution and pharmacokinetics of theaflavin-3, 3'-digallate, the major antioxidant of black tea, in mice. Int J Pharm 2006; 2: 240-6. 
[87] Xu X, Harris KS, Wang HJ, Murphy PA, Hendrich S. Bioavailability of soybean isoflavones depends upon gut microflora in women. J Nutr 1995; 125: 2307-15.

[88] Simons A, Renouf M, Murphy P, Hendrich S. Greater apparent absorption of flavonoids is associated with lesser human fecal flavonoid disappearance rates. J Agric Food Chem 2010; 58: 141-7.

[89] Setchell KDR, Clerici C, Lephart ED, et al. S-Equol, a potent ligand for estrogen receptor $\beta$, is the exclusive enantiomeric form of the soy isoflavone metabolite produced by human intestinal bacterial flora. Am J Clin Nutr 2005; 81: 1072-9.

[90] Chanteranne B, Branca F, Kaardinal A, et al. Food matrix and isoflavones bioavailability in early post menopausal women: A European clinical study. Clin Interv Aging 2008; 3: 711-8.

[91] McCall DO, McGartland CP, McKinley MC, et al. Dietary intake of fruits and vegetables improves microvascular function in hypertensive subjects in a dose-dependent manner. Circulation 2009; 119: 2153-60.

[92] Navab M, Ananthramaiah GM, Reddy ST, et al. The oxidation hypothesis of atherogenesis: the role of oxidized phospholipids and HDL. J Lipid Res 2004; 45: 993-1007.

[93] Kaplan M, Aviram M. Oxidized low density lipoprotein: Atherogenic and proinflammatory characteristics during macrophage foam cell formation. An inhibitory role for nutritional antioxidants and serum paraoxonase. Clin Chem Lab Med 1999; 37: 777-87.

[94] Saura-Calixto F, Goñi I. Antioxidant capacity of the Spanish Mediterranean diet. Food Chem 2006; 94: 442-7.

[95] Terao J, Kawai Y, Murota K. Vegetable flavonoids and cardiovascular disease. Asia Pac J Clin Nutr 2008; 17: 291-3.

[96] Agarwal S, Rao AV. Tomato lycopene and low density lipoprotein oxidation: a human dietary intervention study. Lipids 1998; 33 : 981-4.

[97] Visioli F, Riso P, Grande S, Galli C, Porrini M. Protective activity of tomato products on in vivo markers of lipid oxidation. Eur J Nutr 2003; 42: 201-6.

[98] Basu A, Wilkinson1 M, Penugonda1 K, Simmons1 B, Betts NM, Lyons TJ. Freeze-dried strawberry powder improves lipid profile and lipid peroxidation in women with metabolic syndrome: baseline and post intervention effects. Nutr J 2009; 8: 43-6.

[99] Chang W, Liu J. Effects of kiwifruit consumption on serum lipid profiles and antioxidative status in hyperlipidemic subjects. Int J Food Sci Nutr 2009; 60: 709-16.

[100] Aviram M, Dornfeld L, Rosenblat M, et al. Pomegranate juice consumption reduces oxidative stress, atherogenic modifications to LDL, and platelet aggregation: studies in humans and in the atherosclerotic apolipoprotein E-deficient mice. Am J Clin Nutr 2000; 71: 1062-76.

[101] Aviram M, Rosenblat M, Gaitini D, et al. Pomegranate juice consumption for 3 years by patients with carotid artery stenosis reduces common carotid intima-media thickness, blood pressure and LDL oxidation. Clin Nutr 2004; 23: 423-33.

[102] Kaplan M, Hayek T, Raz A, et al. Pomegranate juice supplementation to atherosclerotic mice reduces macrophages lipid peroxidation, cellular cholesterol accumulation and development of atherosclerosis. J Nutr 2001; 131: 2082-9.

[103] Fuhrman B, Aviram M. Pomegranate and cardiovascular diseases: pomegranate juice polyphenolic antioxidants protect against oxidative stress and atherosclerosis development. Acta Hortic 2007; 744: 205-16.

[104] Gong MK, Garige M, Varatharajalu R, et al. Quercetin upregulates paraoxonase 1 gene expression with concomitant protection against LDL oxidation. Biochem Biophys Res Commun 2009; 379: 1001-4

[105] O'Byrne DJ, Devaraj S, Grundy SM, Jialal I.Comparison of the antioxidant effects of Concord grape juice flavonoids and alpha tocopherol on markers of oxidative stress in healthy adults. Am J Clin Nutr 2002; 76: 1367-74.

[106] Ruel G, Pomerleau S, Couture P, Lamarche B, Couillard C. Changes in plasma antioxidant capacity and oxidized low-density lipoprotein levels in men after short-term cranberry juice consumption. Metabolism 2005; 54: 856-61.

[107] Wang C, Fu H, Chiang M. Cardiovascular disease prevention of cranberry vinegar. Nutr Sci J 2007; 32: 129-32.

[108] Chen CY, Milbury PE, Lapsley K, Blumberg JB. Flavonoids from almond skins are bioavailable and act synergistically with vitamins
$\mathrm{C}$ and $\mathrm{E}$ to enhance hamster and human LDL resistance to oxidation. J Nutr 2005; 135: 1366-73.

[109] Tikkanen MJ, Wahala K, Ojala S, Vihma V, Adlercreutz H. Effect of soybean phytoestrogen intake on low density lipoprotein oxidation resistance. Proc Natl Acad Sci USA 1998; 95: 3106-10.

[110] Mathur S, Devaraj S, Grundy SM, Jialal I. Cocoa products decrease low density lipoprotein oxidative susceptibility but do not affect biomarkers of inflammation in humans. J Nutr 2002; 132: 3663-7.

[111] Osakabe N, Baba S, Yasuda A, et al. Daily cocoa intake reduces the susceptibility of lowdensity lipoprotein to oxidation as demonstrated in healthy human volunteers. Free Radic Res 2001; 34: 93-9.

[112] Rein D, Lotito S, Holt RR, Keen CL, Schmitz HH, Fraga CG. Epicatechin in human plasma: in vivo determination and effect of chocolate consumption on plasma oxidation status. J Nutr 2000; 130: 2109-14.

[113] Wan Y, Vinson JA, Etherton TD, Proch J, Lazarus SA, KrisEtherton PM. Effects of cocoa powder and dark chocolate on LDL oxidative susceptibility and prostaglandin concentrations in humans. Am J Clin Nutr 2001; 74: 596-602.

[114] Engler MB, Engler MM, Chen CY, et al. Flavonoid-rich dark chocolate improves endothelial function and increases plasma epicatechin concentrations in healthy adults. J Am Coll Nutr 2004; 23:197-204.

[115] Kasaoka S, Hase K, Morita T, Kiriyama S. Green tea flavonoids inhibit the LDL oxidation in osteogenic disordered rats fed a marginal ascorbic acid in diet. J Nutr Biochem 2002; 13: 96-102.

[116] Miura Y, Chiba T, Tomita I, et al. Tea catechins prevent the development of atherosclerosis in apoprotein E-deficient mice. J Nutr 2001; 131: 27-32.

[117] O'Reilly JD, Mallet AI, McAnlis GT, et al. Consumption of flavonoids in onions and black tea: lack of effect on $\mathrm{F}_{2}$-isoprostanes and autoantibodies to oxidized LDL in healthy humans. Am J Clin Nutr 2001; 73: 1040-4.

[118] Hirano-Ohmori R, Takahashi R, Momiyama Y, et al. Green Tea Consumption and Serum Malondialdehyde-Modified LDL Concentrations in Healthy Subjects. J Am Coll Nutr 2005; 24: 342-6.

[119] Natella F, Nardini FM, Belelli F, Scaccini C. Coffee drinking induces incorporation of phenolic acids into LDL and increases the resistance of LDL to ex vivo oxidation in humans. Am J Clin Nutr 2007; 86: 604-9.

[120] Kempf SK, Herder C, Erlund I, et al. Effects of coffee consumption on subclinical inflammation and other risk factors for type 2 diabetes: a clinical trial. Am J Clin Nutr 2010; 1: 950-7.

[121] Rifici VA, Schneider SH, Khachadurian AK. Lipoprotein oxidation mediated by J774 murine macrophagesis inhibited by individual red wine polyphenols but not by ethanol. J Nutr 2002; 132: 2532-7.

[122] Frankel EN, Kanner J, German JB, Parks E, Kinsella JE. Inhibition of oxidation of human low-density lipoprotein by phenolic substances in red wine. Lancet 1993; 341: 454-7.

[123] Frankel EN, Waterhouse AL, Kinsella JE. Inhibition of LDL oxidation by resveratrol. Lancet 1993; 341: 1103-4.

[124] Hayek T, Furman B, Vaya JR, et al. Reduced progression of atherosclerosis in apolipoprotein E-deficient mice following consumption of red wine or its polyphenols quercetin or catechin, is associated with reduced susceptibility of LDL to oxidation and aggregation. Arterioscler Thromb Vasc Biol 1997; 17: 2744-52.

[125] Stocker R, O'Halloran RA. Dealcoholized red wine decreases atherosclerosis in apolipoprotein E gene-deficient mice independently of inhibition of lipid peroxidation in the artery wall. Am J Clin Nutr 2004; 79: 123-30.

[126] Prickett CD, Lister E, Collins M, et al. Alcohol: Friend or foe? alcoholic beverage hormesis for cataract and atherosclerosis is related to plasma antioxidant activity nonlinearity. Biol Toxicol Med 2004; 2: 353-70.

[127] Benito S, Buxaderas S, Mitjavila MT. Flavonoid metabolites and susceptibility of rat lipoproteins to oxidation. Am J Physiol 2004 287(6): H2819-24.

[128] Briante R, Febbraio F, Nucci R. Antioxidant/prooxidant effects of dietary non-flavonoid phenols on the $\mathrm{Cu}^{+2}$ induced oxidation of human low-density lipoprotein (LDL). Chem Biodivers 2004; 1 : 1716-29. 
[129] Janisch KM, Williamson G, Needs P, Plumb GW. Properties of quercetin conjugates: modulation of LDL oxidation and binding to human serum albumin. Free Radic Res 2004; 38: 877-84.

[130] Fitzpatrick DF, Coffey RG, Jantzen PT, Endothelium-dependent vasorelaxing activity of wine, grapes, and other plant products. Wine nutritional and therapeutic benefits /. Washington, DC: American Chemical Society, c1997; p. 237-46.

[131] Lopez-Garcia E, Schulze MB, Fung TT, Meigs JB, Rifai N, Manson JAE, Hu FB. Major dietary patterns are related to plasma concentrations of markers of inflammation and endothelial dysfunction. Am J Clin Nutr 2004; 80: 1029-35.

[132] Nettleton JA, Steffen LM, Mayer-Davis EJ, et al. Dietary patterns are associated with biochemical markers of inflammation and endothelial activation in the Multi-Ethnic Study of Atherosclerosis (MESA). Am J Clin Nut 2006; 83: 1369-79.

[133] Cuevas AM, Germain AM. Diet and endothelial function. Biol Res 2004; 37: 225-30

[134] Nielsen DC, Morrow F, Enghusen-Poulsen JD, et al. Supplementation with orange and blackcurrant juice, but not vitamin E, improves inflammatory markers in patients with peripheral arterial disease. Br J Nut 2009; 101: 263-9.

[135] McCarty MF. Scavenging of peroxynitrite-derived radicals by flavonoids may support endothelial NO synthase activity, contributing to the vascular protection associated with high fruit and vegetable intakes. Med Hypotheses 2008; 70: 170-81.

[136] Nigris F, de Williams-Ignarro S, Lerman LO, et al. Beneficial effects of pomegranate juice on oxidation-sensitive genes and endothelial nitric oxide synthase activity at sites of perturbed shear stress. Proc Natl Acad Sci USA 2005; 102: 4896-901.

[137] Kamata, K. Kobayashi, T. Matsumoto, T. Kanie, N. Oda, S. Kaneda, A. Sugiura, M. Effects of chronic administration of fruit extract (Citrus unshiu Marc) on endothelial dysfunction in streptozotocin-induced diabetic rats. Biol Pharm Bull 2005; 28(2): 267-70.

[138] Suzuki A, Yamamoto M, Jokura H, et al. Ferulic Acid Restores Endothelium-Dependent Vasodilation in Aortas of Spontaneously Hypertensive Rats. Am J Hypertens 2007; 20(5): 508-13.

[139] Hassanabad ZF, Jafarzadeh M, Tarhini A, Fatehi M. The antihypertensive and vasodilator effects of aqueous extract from Berberis vulgaris fruit on hypertensive rats. Phytother Res 2005; 19: 222-5.

[140] George TW, Niwat C, Waroonphan S, Gordon MH, Lovegrove JA. Effects of chronic and acute consumption of fruit- and vegetablepuree-based drinks on vasodilation, risk factors for CVD and the response as a result of the eNOS G298T polymorphism. Proc Nutr Soc 2009; 68: 148-61.

[141] Freedman JE, Parker C III, Li L, et al. Select flavonoids and whole juice from purple grapes inhibit platelet function and enhance nitric oxide release. Circulation 2001; 103: 2792-8.

[142] Leikert JF, Rathel TR, Wohlfart P, Cheynier V, Vollmar AM, DirschVM. Red wine polyphenols enhance endothelial nitric oxide synthaseexpression and subsequent nitric oxide release from endothelial cells. Circulation 2002; 106: 1614-7.

[143] Siu-Lung C, Christine CA, Jeffrey A. Red wine polyphenols improve endothelium-dependent dilation in rat cerebral arterioles. J Cardiovasc Pharmacol 2008; 51: 553-8.

[144] Wallerath T, Deckert G, Ternes T, et al. Resveratrol, a polyphenolic phytoalexin present in redwine, enhances expression and activity of endothelial nitric oxidesynthase. Circulation 2002; 106: $1652-8$.

[145] Lorenz M, Wessler S, Follmann E, et al. A constituent of green tea, epigallocatechin-3-gallate, activates endothelial nitric oxide synthase by a phosphatidylinositol-3-OH-kinase-, cAMP-dependent protein kinase-, andAkt-dependent pathway and leads to endothelial-dependent vasorelaxation. J Biol Chem 2004; 279: 6190-5.

[146] Dell'Agli M, Busciala A. Bosisio, E. Vascular effects of wine polyphenols. Cardiovasc Res 2004; 63: 593-602.

[147] Noll C, Hamelet J, Matulewicz E, Paul JL, Delabar JM, Janel N. Effects of red wine polyphenolic compounds on paraoxonase-1 and lectin-like oxidized low-density lipoprotein receptor-1 in hyperhomocysteinemic mice. J Nutr Biochem 2009; 20: 586-96.

[148] Padilla E, Ruiz E, Redondo S, Moscoso AG, Slowing K, Tejerina T. Relationship between vasodilation capacity and phenolic content of Spanish wines. Eur J Pharm 2005; 517: 84-91.
[149] Hijmering ML, De Lange DW, Lorsheyd A, Kraaijenhagen RJ, Van De Wiel A. Binge drinking causes endothelial dysfunction, which is not prevented by wine polyphenols : a small trial in healthy volunteers. Netherlands J Med 2007; 65: 29-35.

[150] Chaves AA, Joshi MS, Coyle CM, et al. Vasoprotective endothelial effects of a standardized grape product in humans. Vascular Pharm 2009; 50: 20-6.

[151] Kirimlioglu V, Sozen H, Turkoglu S, Haberal M. Protective effect of resveratrol, a red wine constituent polyphenol, on rats subjected to portal vein thrombosis. Transplant Proc 2008; 40: 290-2.

[152] Schini-Kerth VB, Auger C, Kim J, Étienne-Selloum N, Chataigneau T. Nutritional improvement of the endothelial control of vascular tone by polyphenols: role of NO and EDHF. Pflugers Arch 2010; 459(6): 853-62.

[153] Naomi FDL, Meghan H, Marie G, Norman KH. Flavanol-rich cocoa induces nitric-oxide-dependent vasodilation in healthy humans. J Hypertens 2003; 21: 2281-6.

[154] Balzer J, Rassaf T, Heiss C, et al. Sustained benefits in vascular function through flavanol-containing cocoa in medicated diabetic patients a double-masked, randomized, controlled trial. J Am Coll Cardiol 2008; 51: 2141-9.

[155] Flammer AJ, Hermann F, Sudano I, et al. Dark chocolate improves coronary vasomotion and reduces platelet reactivity. Circulation 2007; 116: 2376-82.

[156] Grassi D, Desideri G, Necozione S, et al. Blood pressure is reduced and insulin sensitivity increased in glucose-intolerant, hypertensive subjects after 15 days of consuming high-polyphenol dark chocolate. J Nutr 2008; 138: 1671-6.

[157] Shiina Y, Funabashi N, Lee K, et al. Acute effect of oral flavonoidrich dark chocolate intake on coronary circulation, as compared with nonflavonoid white chocolate, by transthoracic Doppler echocardiography in healthy adults. Int J Cardiol 2009; 131: 424-9.

[158] Corti R, Flammer AJ, Hollenberg NK, Lüscher TF. Cocoa and cardiovascular Health. Circulation 2009; 119: 1433-41.

[159] Ardalan MR, Tarzamni MK, Shoja MM, et al. Black tea improves endothelial function in renal transplant recipients. Transplant Proc 2007; 39: 1139-42.

[160] Mario L, Janka U, Ulrich E, Gert B, Karl S, Verena S. Green and black tea are equally potent stimuli of $\mathrm{NO}$ production and vasodilation: new insights into tea ingredients involved. Basic Res Cardiol 2009; 104: 100-10

[161] Nicoline J, Mario L, Amelie V, et al. The efficacy of black tea in ameliorating endothelial function is equivalent to that of green tea. Br J Nutr 2008; 99: 863-8.

[162] Potenza MA, Marasciulo FL, Tarquinio M, et al. EGCG, a green tea polyphenol, improves endothelial function and insulin sensitivity, reduces blood pressure, and protects against myocardial I/R injury in SHR. Am J Physiol Endocrinol Metab 2007; 292: E137887.

[163] Kim JA, Formosa G, Li Y, et al. Epigallocatechin gallate, a green tea polyphenol, mediates NO-dependent vasodilation using signaling pathways in vascular endothelium requiring reactive oxygen species and Fyn. J Biol Chem 2007; 282(18): 13736-45.

[164] Loke WM, Proudfoot JM, Hodgson JM, et al. Specific Dietary Polyphenols Attenuate Atherosclerosis in Apolipoprotein EKnockout Mice by Alleviating Inflammation and Endothelial Dysfunction. Atherscler Thromb Vasc Biol 2010; 30: 749-53.

[165] Papamichael CM, Aznaouridis KA, Karatzis EN, et al. Effect of coffee on endothelial function in healthy subjects: the role of caffeine. Clin Sci (London) 2005; 109: 55-60.

[166] Takashi U, Keiko U, Nishioka K, et al. Effects of acute administration of caffeine on vascular function. Am J Cardiol 2006; 98: 153841.

[167] Riksen NP, Rongen GA, Smits P. Acute and long-term cardiovascular effects of coffee: implications for coronary heart disease. Pharmacol Ther 2009; 121: 185-91.

[168] Buscemi S, Verga S, Batsis JA, et al. Dose-dependent effects of decaffeinated coffee on endothelial function in healthy subjects. Eur J Clin Nutr 2009; 63: 1200-5.

[169] Pérez-Vizcaíno F, Ibarra M, Cogolludo AL, et al. Endotheliumindependent vasodilator effects of the flavonoid quercetin and its methylated metabolites in rat conductance and resistance arteries. J Pharmacol Exp Ther 2002; 302: 66-72. 
[170] Suri S, Liu XH, Rayment S, et al. Quercetin and its major metabolites selectively modulate cyclic GMP-dependent relaxations and associated tolerance in pig isolated coronary artery. Br J Pharm 2010; 159: 566-75.

[171] Gresele P, Pignatelli P, Guglielmini G, et al. Resveratrol, at concentrations attainable with moderate wine consumption, stimulates human platelet nitric oxide production. J Nutr 2008; 138: 1602-8.

[172] Hubbard GP, Wolffram S, Lovegrove JA, Gibbins JM. The role of polyphenolic compounds in the diet as inhibitors of platelet function. Proc Nutr Soc 2003; 62: 469-78.

[173] Shanmuganayagam D, Beahm MR, Osman HE, Krueger CG, Reed JD, Folts JD. Grape seed and grape skin extracts elicit a greater antiplatelet effect when used in combination than when used individually in dogs and humans. J Nutr 2002; 132: 3592-8.

[174] Lange DW, Verhoef S, Gorter G, Kraaijenhagen RJ, Wiel A, Akkerman JWN. Polyphenolic grape extract inhibits platelet activation through PECAM-1: an explanation for the French paradox. Alcoholism: Clin Exp Res 2007; 31: 1308-14.

[175] Crescente M, Jessen G, Momi S, et al. deInteractions of gallic acid, resveratrol, quercetin and aspirin at the platelet cyclooxygenase-1 level - functional and modelling studies. Thromb Haemost 2009; 102: 336-46.

[176] Russo P, Tedesco I, Russo M, Russo GL, Venezia A, Cicala C. Effects of de-alcoholated red wine and its phenolic fractions on platelet aggregation. Nutr Metab Cardiovasc Dis 2001; 11: 25-9.

[177] Erlund I, Koli R, Alfthan G, et al. Favorable effects of berry consumption on platelet function, blood pressure, and HDL cholesterol. Am J Clin Nutr 2008; 87: 323-31.

[178] Duttaroy AK, Jorgensen A. Effects of kiwi fruit consumption on platelet aggregation and plasma lipids in healthy human volunteers. Platelets 2004; 15: 287-92.

[179] Duttaroy AK. Cardiovascular health benefits of tomatoes. CAB Reviews: Perspectives in Agriculture, Veterinary Science, Nutrition and Natural Resources 2008; 3: 52-9.

[180] ZhiRong W, JianGang Z, YuanZhu H, KeJiang C, YiNan X, $\mathrm{Wu}$ JM. Effect of resveratrol on platelet aggregation in vivo and in vitro. Chin Med J (Beijing) 2002; 115: 378-80.

[181] Olas B, Wachowicz B, Tomczak A, Erler J, Stochmal A, Oleszek W. Comparative anti-platelet and antioxidant properties of polyphenol-rich extracts from: berries of Aronia melanocarpa, seeds of grape and bark of Yucca schidigera in vitro. Platelets 2008; 19: 707.

[182] Yamamoto J, Naemura A, Ura M, et al. Testing various fruits for anti-thrombotic effect: I. Mulberries. Platelets 2006; 17: 555-64.

[183] Mattiello T, Trifiro E, Jotti GS, Pulcinelli FM. Effects of pomegranate juice and extract polyphenols on platelet function. J Med Food 2009; 12: 334-9.

[184] Keevil JG, Osman HE, Reed JD, Folts JD. Grape juice, but not orange juice or grapefruit juice, inhibits human platelet aggregation. J Nutr 2000; 130: 53-6.

[185] Bordeaux B, Yanek LR, Moy TF, et al. Casual chocolate consumption and inhibition of platelet function. Prev Cardiol 2007; 10: 17580.

[186] Polagruto JA, Gross HB, Kamangar F, et al. Platelet reactivity in male smokers following the acute consumption of a flavanol-rich grapeseed extract. J Med Food 2007; 10: 725-30.

[187] Rein D, Paglieroni TG, Wun T, et al. Cocoa inhibits platelet activation and function. Am J Clin Nutr 2000; 72: 30-5.

[188] Shenoy SF, Keen CL, Kalgaonkar S, Polagruto JA. Effects of grape seed extract consumption on platelet function in postmenopausal women. Thromb Res 2007; 121: 431-2.

[189] Wang-Polagruto JF, Villablanca AC, Polagruto JA, et al. Chronic consumption of flavanol-rich cocoa improves endothelial function and decreases vascular cell adhesion molecule in hypercholesterolemic postmenopausal women. J Cardiovasc Pharmacol 2006; 47: S177-86.

[190] Rein D, Paglieroni TG, Pearson DA, et al. Cocoa and wine polyphenols modulate platelet activation and function. J Nutr 2000; 130: 2120-6.

[191] Singh I, Quinn H, Mok M, et al. The effect of exercise and training status on platelet activation: do cocoa polyphenols play a role? Platelets 2006; 17: 361-7.

[192] Navarro-Nunez L, Rivera J, Guerrero JA, Martinez C, Vicente V, Lozano ML. Differential effects of quercetin, apigenin and genis- tein on signalling pathways of protease-activated receptors $\mathrm{PAR}_{1}$ and $\mathrm{PAR}_{4}$ in platelets. Br J Pharm 2009; 158: 1548-56.

[193] Hubbard GP, Wolffram S, Lovegrove JA, Gibbins JM. Ingestion of quercetin inhibits platelet aggregation and essential components of the collagen-stimulated platelet activation pathway in humans. J Thromb Haemost 2004; 2: 2138-45.

[194] Hubbard GP, Wolffram S, de Vos R, Bovy A, Gibbins JM, Lovegrove JA. Ingestion of onion soup high in quercetin inhibits platelet aggregation and essential components of the collagen-stimulated platelet activation pathway in man: a pilot study. Br J Nutr 2006; 96: 482-8.

[195] Gonzalez-Correa JA, Navas MD, Munoz-Marin J, Trujillo M, Fernandez-Bolanos J, Cruz JP. Effects of hydroxytyrosol and hydroxytyrosol acetate administration to rats on platelet function compared to acetylsalicylic acid. J Agric Food Chem 2008; 56: 7872-6.

[196] Gonzalez-Correa JA, Lopez-Villodres JA, Asensi R, Espartero JL, Rodriguez-Gutierez G, Cruz JP. Virgin olive oil polyphenol hydroxytyrosol acetate inhibits in vitro platelet aggregation in human whole blood: comparison with hydroxytyrosol and acetylsalicylic acid Br J Nutr 2009; 101: 1157-64.

[197] Steptoe A, Gibson EL, Vuononvirta R, et al. The effects of chronic tea intake on platelet activation and inflammation: a double-blind placebo controlled trial. Atherosclerosis 2007; 193: 277-82.

[198] Hu X, Huang X, Yang X, Chen J. Effects of tea Polyphenols on CBSA-Nephritis rabbits. J Zhejiang Univ (Agriculture and Life Sciences) 2001; 27: 569-74.

[199] Hernandez Figueroa TT, Rodriguez-Rodriguez E, Sanchez-Muniz FJ. The green tea, a good choice for cardiovascular disease prevention? Arch Latinoam Nutr 2004; 54: 380-94.

[200] Hodgson JM, Puddey IB, Burke V, Beilin LJ, Mori TA, Chan SY. Acute effects of ingestion of black tea on postprandial platelet aggregation in human subjects. Br J Nutr 2002; 87: 141-5.

[201] http://www.sciencedirect.com/science?_ob=ArticleURL\&_ udi=B6T1C-4FF9H7Y-4\&_user=403646\&_coverDate $=12 \% 2 \mathrm{~F} 31 \%$ 2F2005\&_rdoc $=1 \&$ \&mt $=$ high \&_orig $=$ search \&_sort $=$ d\&_docanchor $=\&$ view $=c \& \_$acct $=C 000013498 \& \_$version $=1 \&$ \&urlVersion $=$ $0 \&$ _userid $=403646 \& \mathrm{md} 5=\mathrm{b} 3 \mathrm{e} 555 \mathrm{e} 1 \mathrm{~d} 39 \mathrm{e} 1 \mathrm{a} 047 \mathrm{e} 78 \mathrm{~d} 3 \mathrm{a} 8459 \mathrm{~d} 3 \mathrm{~d} 0$ 4 - cor1\#cor1 Rechner AR, Kroner C. Anthocyanins and colonic metabolites of dietary polyphenols inhibit platelet function. Thromb Res 2005; 116: 327-34.

[202] Pignatelli P, Santo S, Buchetti B, Sanguigni V, Brunelli A, Violi F. Polyphenols enhance platelet nitric oxide by inhibiting protein kinase C-dependent NADPH oxidase activation: effect on platelet recruitment. FASEB J 2006; 20: 1082-9.

[203] Ferreres F, Gil MI, Castaner M, Tomas-Barberan FA. Phenolic metabolites in red pigmented lettuce (Lactuca sativa). Changes with minimal processing and cold storage. J Agric Food Chem 1997; 45: 4249-54.

[204] Ferreres F, Gil MI, Tomas-Barberan, FA Anthocyanins and flavonoids from shredded red onions and changes during storage in perforated films. Food Res Int 1996; 29: 389-95.

[205] DuPont SM, Mondin Z, Williamson G, Price KR. Effect of variety, processing and storage on the flavonoid glycoside content and composition of lettuce and endive. J Agric Food Chem 2000; 48: 3957-64.

[206] Kalt W. Effects of production and processing factors on major fruit and vegetable antioxidants. J Food Sci 2005; 70: 11-9.

[207] Hakkinen SH, Karenlampi SO, Mykkanen HM, Torronen AR. Influence of domestic processing and storage on flavonol contents in berries. J Agric Food Chem 2000; 48: 2960-5.

[208] Salinas-Moreno Y, Martinos-Bustos F, Soto-Hernandez M, OrtegaPaczka R, Arellano-Vazquez JL. Effect of alkaline cooking process on anthocyanins in pigmented maize grain. Agrosciencia 2003; 37: 617-28.

[209] Price KR, Casuscelli F, Colquhoun IJ, Rhodes MJC. Composition and content of flavonol glycosides in broccoli florets (Brassica olearacea) and their fate during cooking. J Sci Food Agric 1998; 77: 468-72.

[210] Faller ALK, Fialho E. The antioxidant capacity and polyphenol content of organic and conventional retail vegetables after domestic cooking. Food Res Int 2009; 42: 210-5.

[211] Verkerk R, Dekker M. Glucosinolates and Myrosinase Activity in Red Cabbage (Brassica oleracea L. Var. Capitata f. rubra DC.) 
after Various Microwave Treatments J Agric Food Chem 2004; 52: 7318-23.

[212] Laparra MJ, Glahn RP, Miller DD. Bioaccessibility of phenols in common beans (Phaseolus vulgaris $\mathrm{L}$.) and iron $(\mathrm{Fe})$ availability to Caco-2 cells. J Agric Food Chem 2008; 56: 10999-1005.

[213] Kalogeropoulos N, Mylona A, Chiou A, Ioannou MS, Andrikopoulos NK. Retention and distribution of natural antioxidants (a-tocopherol, polyphenols and terpenic acids) after shallow frying of vegetables in virgin olive oil. LWT-Food Sci Technol 2007; 40: 1008-17.

[214] Philpott M, Gould KS, Markham KR, Lewthwaite SL, Ferguson LR. Enhanced colouration reveals high antioxidant potential in new sweet potato cultivars. J Sci Food Agric 2003; 83: 1076-82.

[215] Brenes M, Garciäa AM, Dobarganes C, Velasco J, Romero CN. Influence of Thermal Treatments Simulating Cooking Processes on the Polyphenol Content in Virgin Olive Oil. J Agric Food Chem 2002; 50: 5962-7.

[216] Sultana B, Anwar F, and Iqbal S. Effect of different cooking methods on the antioxidant activity of some vegetables from Pakistan. J Food Sci Technol 2003; 43: 560-7.

[217] Yadav SK, Sehgal S. Effect of domestic processing and cooking methods on total, $\mathrm{HCl}$ extractable iron and in vitro availability of iron in bathua and fenugreek leaves. Nutr Health 2003; 17: 61-3.

[218] Pawar VD, Machewad GM. Processing of foxtail millet for improved nutrient availability. J Food Process Preserv 2006; 30: 26979.

[219] Khandelwal S, Udipi, SA, Ghugre P. Polyphenols and tannins in Indian pulses: effect of soaking, germination and pressure cooking. Food Res Intl 2010; 43: 526-30.

[220] Jane H, Monique B, Francoise N, Francois P, Jean, D. Effects of fermentation on the phytochemical composition and antioxidant properties of soy germ. Food Chem 2008; 109: 709-21.

[221] Devic E, Guyot S, Daudin JD, Bonazzi C. Effect of Temperature and Cultivar on Polyphenol Retention and Mass Transfer during Osmotic Dehydration of Apples. J Agric Food Chem 2010; 58: 606-14.

[222] Agarwal A, Shen H, Agarwal S, Rao AV. Lycopene content of tomato products: its stability, bioavailability and in vivo antioxidant properties. J Med Food 2001; 4: 9-15.

[223] Gärtner C, Stahl W, Sies H. Lycopene is more bioavailable from tomato paste than from fresh tomatoes. Am J Clin Nutr 1997; 66: 116-22.

[224] Porrini M, Riso P, Testolin G. Absorption of lycopene from single or daily portions of raw and processed tomato. Br J Nutr 1998; 80: 353-61.

[225] Boileau TWM, Boileau AC, Erdman JW. Bioavailability of all-trans and cis-isomers of lycopene. Exp Biol Med 2002; 227: 914-9.

[226] Fielding JM, Rowley KG, Cooper PO, Dea K. Increases in plasma lycopene concentration after consumption of tomatoes cooked with olive oil. Asia Pacific J Clin Nutr 2005; 14: 131-6.

[227] Padula M, Rodriguez-Amaya DB. Changes in individual carotenoids and vitamin $\mathrm{C}$ in processing and storage of guava juice. Acta Aliment 1986; 16: 209-16.

[228] Hollands W, Brett GM, Radreau P, et al. Processing blackcurrants dramatically reduces the content and does not enhance the urinary yield of anthocyanins in human subjects. Food Chem 2008; 108: 869-78.

[229] Roura E, Andres-Lacueva C, Estruch R, et al. Milk does not affect the bioavailability of cocoa powder flavonoid in healthy human. Ann Nutr Metab 2007; 51: 493-8.

[230] Roura E, Andres-Lacueva C, Estruch R, et al. The effects of milk as a food matrix for polyphenols on the excretion profile of cocoa (-)-epicatechin metabolites in healthy human subjects. Br J Nutr 2008; 100: 846-51.

[231] Serafini M, Bugianesi R, Maiani G, Valtuena S, De Santis S, Crozier A. Plasma antioxidants from chocolate. Nature 2003; 424: 1013-5.

[232] Schroeter H, Holt RR, Orozco TJ, Schmitz HH, Keen CL. Nutrition: Milk and absorption of dietary flavanols. Nature 2003; 426: 787-8.

[233] Schramm DD, Karim M, Schrader HR, et al. Food effects on the absorption and pharmacokinetics of cocoa flavanols. Life Sci 2003; 73: 857-69.
[234] van het Hof KH, Kivits GA, Weststrate JA, Tijburg LB. Bioavailability of catechins from tea: The effect of milk. Eur J Clin Nutr 1998; 52: 356-9.

[235] D'Archivio M, Filesi C, Varì R, Scazzocchio R, Masella R. Bioavailability of the polyphenols: Status and controversies. Int J Mol Sci 2010; 11: 1321-42.

[236] Tuck KL, Freeman MP, Hayball PJ, Stretch GL, Stupans I. The in vivo fate of hydroxytyrosol and tyrosol, antioxidant phenolic constituents of olive oil, after intravenous and oral dosing of labeled compounds to rats. J Nutr 2001; 131: 1993-6.

[237] Mullen W, Archeveque MA, Edwards CA, Matsumoto H, Crozier A. Bioavailability and metabolism of orange juice flavanones in humans: Impact of a full-fat yogurt. J Agric Food Chem 2008; 56: 11157-64.

[238] Goldberg DM, Yan J, Soleas GJ. Absorption of three wine-related polyphenols in three different matrices by healthy subjects. Clin Biochem 2003; 36: 79-87.

[239] Tew BY, Xu X, Wang HJ, Murphy PA. Hendrich S. A diet high in wheat fiber decreases the bioavailability of soybean isoflavones in a single meal fed to women. J Nutr 1996; 126: 871-7.

[240] Wang L, Yin L, Li D, et al. Influences of processing and $\mathrm{NaCl}$ supplementation on isoflavone contents and composition during douchi manufacturing. Food Chem 2007; 101: 1247-53.

[241] Pascual-Teresa ST, Hallund J, Talbot D, et al. Absorption of isoflavones in humans: effects of food matrix and processing. $\mathbf{J}$ Nutr Biochem 2006; 17: 257-64.

[242] Gu L, House SE, Rooney LW, Prior RL. Source Sorghum extrusion increases bioavailability of catechins in weanling pigs. J Agric Food Chem 2008; 56: 1283-8.

[243] Bugianesi R, Salucci M, Leonardi C, et al. Effect of domestic cooking on human bioavailability of naringenin, chlorogenic acid, lycopene and betacarotene in cherry tomatoes. Eur J Nutr 2004; 43: 360-6.

[244] Brown ED, Micozzi MS, Craft NE, et al. Plasma carotenoids in normal men after a single ingestion of vegetables or purified $\beta$ carotene. Am J Clin Nutr 1989; 49: 1258-65.

[245] Pyo YH, Lee TC, Lee YC. Effect of lactic acid fermentation on enrichment of antioxidant properties and bioactive Isoflavones in soybean. J Food Sci 2005; 70: 215-20.

[246] Choi Y, Kim Y, Ra K, Suh H. Characteristics of fermentation and bioavailability of isoflavones in Korean soybean paste (doenjang) with application of Bacillus sp KH-15. Int J Food Sci Technol 2007; 42: 1497-503.

[247] Kuo LC, Cheng WY, Wu RY, Huang CJ, Lee KT. Hydrolysis of black soybean isoflavone glycosides by Bacillus subtilis natto. Appl Microbiol Biotechnol 2006; 73: 314-20.

[248] Koh E, Mitchell AE. Urinary isoflavone excretion in Korean adults: comparisons of fermented soybean paste and unfermented soy flour. J Sci Food Agric 2007; 87: 2112-20.

[249] Wei QK, Chen TR, Chen JT. Use of Bacillus subtilis to enrich isoflavone aglycones in fermented natto. J Sci Food Agric 2008; 88: 1007-11.

[250] Chang TS, Ding HY, Tai SSK, Wu CY. Metabolism of the soy isoflavones daidzein and genistein by fungi used in the preparation of various fermented soybean foods. Biosci Biotechnol Biochem 2007; 71: 1330-3.

[251] Kano M, Takayanagi T, Harada K, Sawada S, Ishikawa F. Bioavailability of isoflavones after ingestion of soy beverages in healthy adults. J Nutr 2006; 136: 2291-6.

[252] Cassidy A, Brown JE, Hawdon A, et al. Factors affecting the bioavailability of soy isoflavones in humans after ingestion of physiologically relevant levels from different soy foods. J Nutr 2006; 136: 45-1.

[253] Franke AA, Ashburn1 LA, Kakazu1 K, Suzuki S, Wilkens LR, Halm BM. Apparent bioavailability of isoflavones after intake of liquid and solid soya foods. Br J Nutr 2009; 102: 1203-10.

[254] McDougall GJ, Dobson P, Smith P, Blake A, Stewart D. Assessing potential bioavailability of raspberry anthocyanins using an in vitro digestion system. J Agric Food Chem 2005; 53: 5896-904.

[255] Brown Mj, Ferruzzi MG, Nguyen ML, et al. Carotenoid bioavailability is higher from salads ingested with full-fat than with fatreduced salad dressings as measured with electrochemical detection. Am J Clin Nutr 2004; 80: 396-403. 
[256] Dimitrov NV, Meyer C, Ullrey DE, et al. Bioavailability of beta-carotene in humans. Am J Clin Nutr 1988; 48: 298-304.

[257] Peters CM, Green RJ, Janle EM, Ferruzzi MG. Formulation with ascorbic acid and sucrose modulates catechin bioavailability from green tea. Food Res Int 2010; 43: 95-102.

[258] Green RJ, Murphy AS, Schulz B, Watkins BA, Ferruzzi MG. Common tea formulations modulate in vitro digestive recovery of green tea catechins. Mol Nutr Food Res 2007; 51: 1152-62.
[259] Ferruzzi MG, Green RJ, Peters CM, Neilson AP, Janle EM. The influence of food formulation on digestive behavior and bioavailability of catechin polyphenols. Acta Hortic 2009; 841: 121-7.

[260] Shoba G, Joy D, Joseph T, Majeed M, Rajendran R, Srinivas PS. Influence of piperine on the pharmacokinetics of curcumin in animals and human volunteers. Planta Med 1998; 64: 353-6.

[261] Lambert JD, Hong J, Kim DH, Mishin VM, Yang CS. Piperine enhances the bioavailability of the tea polyphenol (2)epigallocatechin-3-gallate in mice. J Nutr 2004; 134: 1948-52.

(c) Shivashankara and Acharya; Licensee Bentham Open.

This is an open access article licensed under the terms of the Creative Commons Attribution Non-Commercial License (http://creativecommons.org/licenses/ by-nc/3.0/) which permits unrestricted, non-commercial use, distribution and reproduction in any medium, provided the work is properly cited. 